\title{
PARTICIPATORY ACTION RESEARCH DALAM PENGEMBANGAN KEWIRAUSAHAAN DIGITAL DI PESANTREN PERKOTAAN
}

\author{
Ahmad Syafii Rahman1)*), Cipto Sembodo²), Retno Kurnianingsih3), \\ Faishol Razak4), M. Nur Kholis Al Amin5) \\ 1,2,3)Universitas Cokroaminoto Yogyakarta, 4)PP. Al-Muayyad Solo, \\ 5)UIN Raden Mas Said Surakarta \\ 1)sunksam3@gmail.com, 2)c.sembodo@gmail.com, 3)retnokurnianing84@gmail.com \\ 4)faisalrazak@gmail.com, 5)nurkholis.alamin@iain-surakarta.ac.id
}

*Penulis koresponden

\begin{tabular}{|l|l|l|}
\hline Diajukan: 30-05-2021 & Diterima: 10-06-2021 & Diterbitkan: 12-06-2021 \\
\hline
\end{tabular}

\begin{abstract}
Al-Muayyad Islamic boarding school as one of the oldest pesantren in the urban area of Surakarta is encouraged to become an organ of driving entrepreneurship based on Islamic boarding schools in the field of digital economy through a participatory action research (PAR) approach. The choice is because it has the characteristic of a joint process between subjects. Researchers as trigger and students of Al-Muayyad are positioned as subjects who are active actors with a myriad of potential knowledge and socio-economic experience. With the inclusion of entrepreneurial influence in urban pesantren such as in al-Muayyad, students can be directly involved through the use of digital-based social media in marketing and introducing local products and potentials around the pesantren or their place of origin.
\end{abstract}

Keywords: PAR, entrepreneurship, urban pesantren

Abstrak: Pondok pesantren Al-Muayyad sebagai salah satu pesantren tertua di wilayah perkotaan Surakarta dipacu untuk menjadi sebagai organ penggerak kewirausahaan berbasis pesantren bidang ekonomi digital melalui pendekatan participatory action research (PAR). Pendekatan PAR dipilih karena memiliki ciri khas proses bersama-sama antar subyek. Peneliti sebagai pemantik dan santri Al-Muayyad diposisikan sebagai subjek pelaku yang aktif dengan segudang potensi pengetahuan dan pengalaman sosial ekonominya. Dengan telah masuknya pengaruh kewirausahaan dalam pesantren perkotaan seperti di alMuayyad, maka santri bisa terlibat langsung melalui pemanfaatan media sosial berbasis digital dalam memasarkan dan memperkenalkan produk serta potensi lokal yang ada di sekitar pesantren ataupun tempat asalnya.

Kata Kunci: PAR, kewirausahaan, pesantren perkotaan 


\section{A. Pendahuluan}

Pengembangan pribadi berkewirausahaan bisa dilakukan sejak dini.

Keluarga menjadi lingkungan awal pengembangannya sebelum seseorang bersekolah dan berlanjut ketingkat selanjutnya². Penanaman kemandirian pada tingkat dini dan dasar mengutumakan pada internalisasi nilai-nilai kemandirian, ${ }^{2}$ dan kemasyarakatan. ${ }^{3}$ Sampai dewasa bahkan tindak lanjutnya masih dibutuhkan termasuk bagi mereka yang sudah dewasa. 4 Pemilihan bidang kewirausahaan juga disesuaikan dengan minat kemampuan pribadi maupun komunitas yang didukung dengan kondisi lingkungan sekitar.5

Ansori melihat potensi tanam palawija dalam membangun sikap kewirausahaan Santri di pedesaan Kabupten Ciamis. ${ }^{6}$ Di tahun yang sama Chotimah mengkaji model pendidikan kewirausahaan dan strategi pengajarannya di pondok pesantren Sidogiri Pasuruan dengan pendekatan kualitatif. Kesimpulannya, "Nilai-nilai kewirausahaan yang diinternalisasikan di pondok pesantren Sidogiri adalah nilai kewirausahaan yang berbasis ibadah. stateginya santri dilatih untuk mengelola lembaga ekonomi yang ada di pondok pesantren di bawah pantauan dan bimbingan dari kiai dan pengurus pondok pesantren."7 Muhaimin melihat implementasi program mengembangkan mental kewirausahaan santri di Pondok Pesantren Riyadlul Jannah Mojokerto

${ }^{1}$ Fattah Setiawan Santoso, "Lingkungan Keluarga Sebagai Awal Pengembangan Kewirausahaan Islam," Nuansa Akademik: Jurnal Pembangunan Masyarakat 5, no. 1 (Juni 16, 2020): 13-22.

2 Wiranthi Prastomo et al., "Hizbul Wathan Bagi Pendidikan Kemandirian Tingkat Sekolah Dasar," Nuansa Akademik: Jurnal Pembangunan Masyarakat 4, no. 1 (Juni 25, 2019): 47-62.

3 Ahmad Nadjib H. et al., "Penanaman Nilai-Nilai Kemasyarakatan Di Pesantren Modern," Nuansa Akademik: Jurnal Pembangunan Masyarakat 4, no. 1 (Juni 25, 2019): 17-32.

4 Umi Musaropah et al., "Pengembangan Kewirausahaan Berbasis Industri Kreatif Bagi Jamaah Wanita Majelis Taklim Di Desa Kepek," Nuansa Akademik: Jurnal Pembangunan Masyarakat 4, no. 2 (Desember 28, 2019): 79-90.

5 Lukman Fauroni, Munawar Ahmad, dan Awan Kostradiharto, PTKI Entrepreneur Gagasan dan Praktik, ed. Erham Budi Wiranto (Yogyakarta: Kurnia Kalam Semesta, 2016).

6 Ansori Ansori, "Model Pengembangan Kewirausahaan Santri Melalui Pondok Pesantren Berbasis Budaya Agribisnis Tanaman Palawija,” Didaktik 8, no. 1 (2014).

7 Chusnul Chotimah, "Pendidikan Kewirausahaan Di Pondok Pesantren Sidogiri Pasuruan,” Inferensi 8, no. 1 (September 2014): 114-136. 
bersifat bebas, mudah, dan tidak mengikat. Namun pihak Pondok Pesantren memiliki target atau sasaran yang diharapkan mengikuti program pengembangan mental kewirausahaan santri.

Penelitian Mustofa terkait perkembangan model kemandirian yang diimplementasikan di pesantren Mukmin Mandiri yang mengandalkan tata kelola agrobisnis modern. Yakni, memiliki SDM mumpuni, alat produksi, dan hal-hal lainnya. Yang lain adalah PP. Nurul Karomah yang mengorientasikan bisnis pertanian di pondok pesantrennya pada proses pengambilan laba langsung tanpa mereproduksi menjadi produk baru secara masif. 8 Fatma Sari mendukung temuan bahwa mengembangkan kewirausahaan di pesantren untuk kemajuan perekonomian guna menopang laju kesejahteraan bagi seluruh penghuni pesantren tanpa mengabaikan tradisi pendidikan pesantren pada umunya, yaitu sekolah, ngaji dan masih banyak lagi kegiatan yang dapat membentuk karakter anak yang menjadi lebih baik.

Widodo, Kamardiani, dan Aini mengadakan pengabdian masyarakat di pesantren Asy Syifa' dan Ar Rahmah yang fokus hafalan AlQur'an (tahfidul Qur'an).9 Pengembangan pendidikan kewirausahaan kepada santri berupa usaha jamur tiram. Kegiatan tersebut dilakukan dengan pelatihan dan pendampingan usaha produksi. pelatihan pengolahan jamur tiram. Kegiatan tersebut mampu meningkatkan ketrampilan santri untuk mengusahakan jamur tiram dan juga pengolahan jamur tiram. Kegiatan ini mampu membangkitkan motivasi santri untuk berwirausaha. Sedangkan Israfil meneliti kewirausahaan di pesantren pedesaan lainnya dan mendukung peran figur pimpinan dalam menggagas kewirausahaan. ${ }^{10}$ Penelitian kualitatif di Pesantren Darul Khair oleh Masing menunjukkan pengelolaan usaha pertukangan kayu, peternakan

8 Ali Mustofa, "Manajemen Kewirausahaan Pondok Pesantren Berbasis Agrobisnis (Studi Kasus di PP Mukmin Mandiri dan PP Nurul Karomah),” Jurnal Kependidikan Islam 6, no. 2 (2015): 25-48.

9 Widodo Widodo, Diah Rina Kamardiani, dan Lis Noer Aini, "Kewirausahaan Jamur Tiram Di Pondok Pesantren,” BERDIKARI : Jurnal Inovasi dan Penerapan Ipteks 4, no. 1 (Februari 2016): 23-30.

10 Israfil Israfil, "Pesantren dan Kewirausahaan (Studi terhadap Pesantren Darul Khair Masing Kabupaten Banggai)," Equilibrium: Jurnal Pendidikan 5, no. 2 (Januari 2017): 160-168. 


\section{AS. Rahman, C. Sembodo, R. Kurnianingsih, F. Razak, MNK. Al Amin}

sapi, perkebunan, persawahan dan koperasi pesantren di dalamnya. Seluruh aset usaha dan hasil usaha diserahkan kepada yayasan secara periodik setiap bulannya.

Pengembangan kewirausahaan di pesantren masih didominasi dengan pemanfaatan keunggulan geografis daerah pedesaan. sementara di wilayah perkotaan, pesantren sekarang semakin menjamur sehingga memerlukan pengembangan lebih lanjut. Dalam hal ini, kewirausahaan dengan dukungan dari kebijakan ekonomi pemerintah dapat menjadi celah untuk dikembangkan ${ }^{11}$.

Dewasa ini kewirausahaan kreatif berbasis media sosial digital sedang digalakkan oleh pemerintah. ${ }^{12}$ Konsep ekonomi baru itu mengintensifkan informasi digital dan kreativitas dengan mengandalkan sumber daya ide dan pengetahuan sebagai faktor produksi utama. Keuntungannya bukan hanya laba tetapi juga membuat lapangan pekerjaan baru berdampak meningkatkan kesejahteraan serta menggerakan motor perekonomian bangsa. Konsep ini, sesuai dengan prediksi Howkins, pengarang The Creative Economy, orang-orang yang memiliki ide akan lebih kuat dibandingkan yang bekerja dengan mesin produksi atau pemilik mesin itu sendiri 13 .

Pesantren perkotaan sebagai lembaga sosial ekonomi pendidikan menempati posisi strategis dalam pengembangan ekonomi kreatif melalui penyiapan sumber daya manusia dan potensi ekonomi yang ada di pesantren dan lingkungannya. ${ }^{4}$ Dengan posisi itu, dalam sejarah bangsa 2010)

${ }^{11}$ Soetomo, Strategi Pembangunan Masyarakat (Yogyakarta: Pustaka Pelajar,

12 Nia Juliawati, "Membangun Kewirausahaan: antara Digital Ekonomy dan Human Economy" (2018): 1-24; Keumala Hayati dan Indra Caniago, "Kewirausahaan Teknologi Digital: Potensi Pemberdayaan Pebisnis Milenial," in Prosiding Seminar Nasional Fisip Unila (SEFILA)-3 Tahun 2019 Agenda Baru Pembangunan Indonesia Berbasis Local Knowledge (Metro: Universitas Lampung, 2019), 135-138.

${ }^{13}$ Hayati dan Caniago, "Kewirausahaan"

14 R Lukman Fauroni, Model Bisnis ala Pesantren, Filsafat Ukhuwah Menembus Hypermarket Memberdayakan Ekonomi Umat (Yogyakarta: Kaukaba-Bisyar consulting, 2014); Sarah Fiebrina Heraningsih, R. Rainiyati, dan Ahmad Riduan, "Enhanching Santri's Capabilities through the Skills to Convert Used Goods into Artistic Products in the Sungai Duren Village" in Proceeding of Community Development, vol. 2, 2019, 379; Zamakhsyari Dhofier, Tradisi Pesantren Memadu Modernitas untuk Kemajuan Bangsa (Yogyakarta: Nawesea Press, 2009); Israfil, "Pesantren." 
Indonesia, Perannya dalam pengembangan kebangsaan Indonesia telah diakui. ${ }^{15}$

Nugroho telah menyimpulkan arti penting pesantren bagi pengembangan kesejahteraan masyarakat sekitarnya. ${ }^{16}$ Peran pesantren dalam bidang ekonomi kini semakin dirasakan penguatannya, seirama perkembangan ekonomi Islam di Indonesia. Kharisma kyai perlu diberdayakan tidak sebatas pengelolaan dan organisasi pendidikan pesantren, sehingga bisa diperluas dalam lingkup menyejahterakan masyarakat.

Pesantren Al-Muayyad Surakarta merupakan pesantren Al-Quran tertua di kotanya. Sejak tahun 1991 pesantren Al-Muayyad telah memiliki koperasi pondok pesantren, bahkan telah dirintis sejak tahun 1976. Kopontrennya telah memiliki berbagai unit usaha di antaranya, minimarket sejak tahun 2007, bengkel sepeda motor, 2006, toko alat tulis dan fotocopy serta wartel, serta simpan pinjam syariah. Unit-unit usaha ini berada dalam satu naungan yang kepengurusannya diisi oleh para guru. Sedangkan pengelolaan unit-unit usaha dilakukan oleh alumni.

Namun demikian, dalam pengembangan unit-unit usaha ini perkembangannya kurang pesat. Hal ini terkendala dengan sumber daya pengelolanya, yang sering berganti-ganti yaitu ketika santri pengelola unit usaha sudah lulus dari pendidikan sekolah/ madrasah dan pesantrennya. Pada sisi lain, disebabkan oleh sistem manajemen yang masih sederhana.

Pendampingan dari kalangan perguruan Tinggi menjadi pemicu penting dalam pembangunan budaya wirausaha di kalangan santri. ${ }^{17}$ Prosesnya dipandu oleh sejumlah dosen PTKI bidang kewirausahaan Islami, sebagai mata kuliah penciri. Dengan kekuatan jaringan pengusaha

15 Imroatun Imroatun, "Kontribusi Lembaga Pendidikan Agama Islam Dalam Penguatan Identitas Bangsa," Jurnal Ilmiah Bidang pendidikan Studia Didaktika 8, no. 1 (2016).

16 Taufik Nugroho, "Reorientasi Peranan Pesantren Pada Era Pembangunan Menuju Partisipasi Pemberdayaan Masyarakat Bawah,” Ulumuddin: Jurnal Ilmu-ilmu Keislaman 7, no. 2 (2017): 147-155.

17 Bandoko Bandoko, A Turmudzi, dan M.N.K Al Amin, "Pemberdayaan Usaha Maz Zakki Tahun Pada Badan Amil Zakat Nasional Kota Yogyakarta,” Nuansa Akademik: Jurnal Pembangunan Masyarakat 5, no. 1 (Juni 16, 2020): 53-62; Fauroni, Ahmad, dan Kostradiharto, PTKI. 


\section{AS. Rahman, C. Sembodo, R. Kurnianingsih, F. Razak, MNK. Al Amin}

muslim Yogyakarta dan Surakarta termasuk beberapa dosen kewirausahaan Islami yang dipadukan dengan potensi ekonomi pesantren Al-Muayyad,. maka program pendampingan kewirausahaan kreatif di pesantren perkotaan dipilih dengan pendekatan participatory action research (PAR).

Pengabdian mengarahkan kepada model pengembangan yang sesuai dengan situasi dan kondisi pesantren. Berbeda dengan penelitian dan pengabdian kepada masyarakat sebelumnya, pengembangan kewirausahaan ini diterapkan di pesantren perkotaan. Perkembangan cepat dalam perkotaan tentu memerlukan mental usaha yang cepat tanggap terhadap perkembangan teknologi. Kesadaran terhadap kewirausahaan berbasis media sosial dijital yang sesuai dengan irama ekonomi perkotaan menjadi pilihan utama.

\section{B. Metode}

Keberadaan koperasi pondok pesantren Al-Muayyad sebagai organ penggerak ekonomi pesantren akan dipacu secara lebih aktif dan lebih luas ke pengembangan ekonomi kreatif khususnya kewirausahaan kreatif berbasis digital melalui pendekatan participatory action research (PAR). Pendekatan yang juga umum dalam pemberdayaan masyarakat bidang lingkungan hidup. ${ }^{18}$

Pendekatan PAR dipilih karena memiliki ciri khas proses bersamasama antara subjek penelitian dan peneliti sebagai pemantik. ${ }^{19}$ Dalam menetapkan rencana aksi, melaksanakan, mengevaluasi dan merefleksikan pasca pelaksanaan rencana aksi dalam mencari solusi-solusi hingga menemukan collective statement yang dipahami secara bersamasama, sehingga kekuatan potensi komunitas akan dikeluarkan secara optimal 20. Komunitas masyarakat pesantren Al-Muayyad diposisikan

18 Difla Nadjih dan F Setiawan Santoso, "Sosialisasi Fikih Lingkungan Usulan Pemberdayaan Majelis Taklim Di Desa Nelayan," Ulumuddin: Jurnal Ilmu-ilmu Keislaman 5, no. 2 (2015): 65-73.

19 Fran Baum, Colin MacDougall, dan Danielle Smith, "Participatory action research," Journal of Epidemiology and Community Health 60, no. 10 (Oktober 2006): 854-857; Rianingsih Djohani, ed., Berbuat Bersama Berperan Setara: Acuan Penerapan Participatory Rural Appraisal (Bandung: Studio Driya Media, 1996).

20 Djohani, Berbuat. 
sebagai subjek pelaku yang aktif dengan segudang potensi pengetahuan dan pengalaman sosial ekonominya.

Gambar 1

Alur PAR

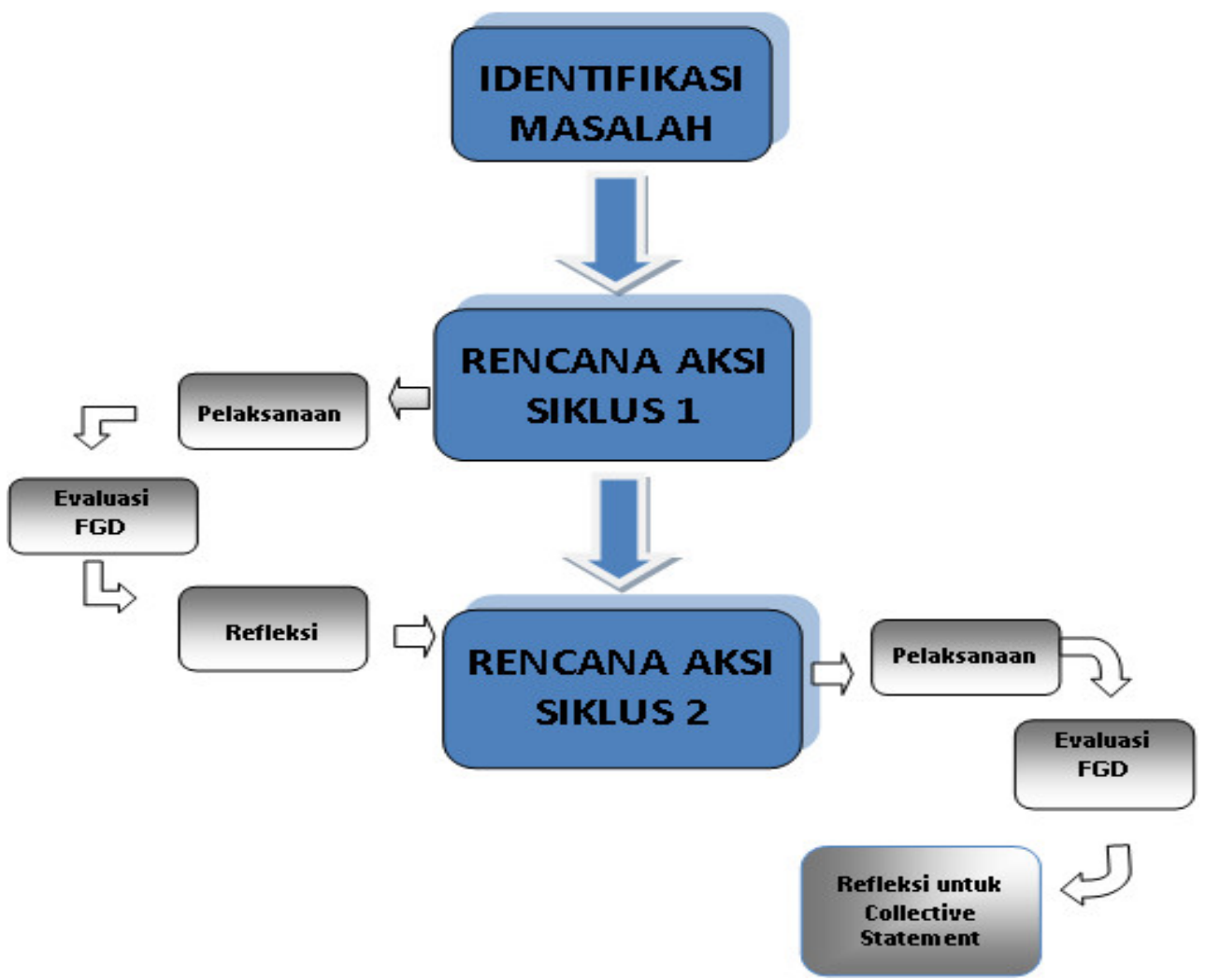

\section{Pelaksanaan}

Sosialisasi

Kegiatan pengabdian masyarakat di Pesantren Al-Muayyad Surakarta terlebih dahulu dilakukan sosialisasi. Maksudnya adalah penyebaran/disseminasi informasi kepada semua pihak yang terkait dan berkepentingan mengenai seluruh kegiatan yang akan dilaksanakan. Dengan arti demikian, maka sosialisasi dapat disebut sebagai pendahuluan atau pembuka kegiatan yang dapat menandai dimulainya tahap demi tahap pelaksanaan pengabdian kepada masyarakat dimaksud.

Ada beberapa tahap sosialisasi kegiatan pengabdian kepada masyarakat ini kepada semua pihak yang terkait dan berkepentingan. Pertama adalah sosialisasi kepada pihak pengelola dan pengasuh 
pesantren mitra pengabdian masyarakat ini. Sosialisasi ini mutlak diperlukan sebagai jalan untuk membuka relasi dan kerja sama yang sangat diperlukan dalam proses-proses berikutnya. Pimpinan dan pengasuh Pesantren Al-Muayyad merupakan subjek mitra pengabdian yang akan menjalankan proses manjerial terkait dengan waktu pembelajaran dan pelatihan sesuai tema pengabdian yang akan dilaksanakan.

Bentuk konkrit dari sosialiasi tahap pertama ini adalah "silaturahmi" dengan pihak pengasuh Pesantren Al-Muayyad dan ditindaklanjuti dengan "kunjungan" kepada Pimpinan dan pengasuh Pesantren Al-Muayyad Surakarta oleh Tim Pengabdian Masyarakat. Hal ini Sekaligus menandai kerja sama yang baik dengan mitra pengabdian kami. Al-hamdulillah hal ini telah dapat dilaksanakan dengan baik, lancar dan membahagiakan. Pimpinan Pesantren Al-Muayyad Surakarta berkenan menerima kehadiran dan maksud baik pengabdian masyarakat dan bersedia menjadi mitra kami.

Gambar 1

Kunjungan ke Pengasuh Pesantren Al-Muayyad Surakarta

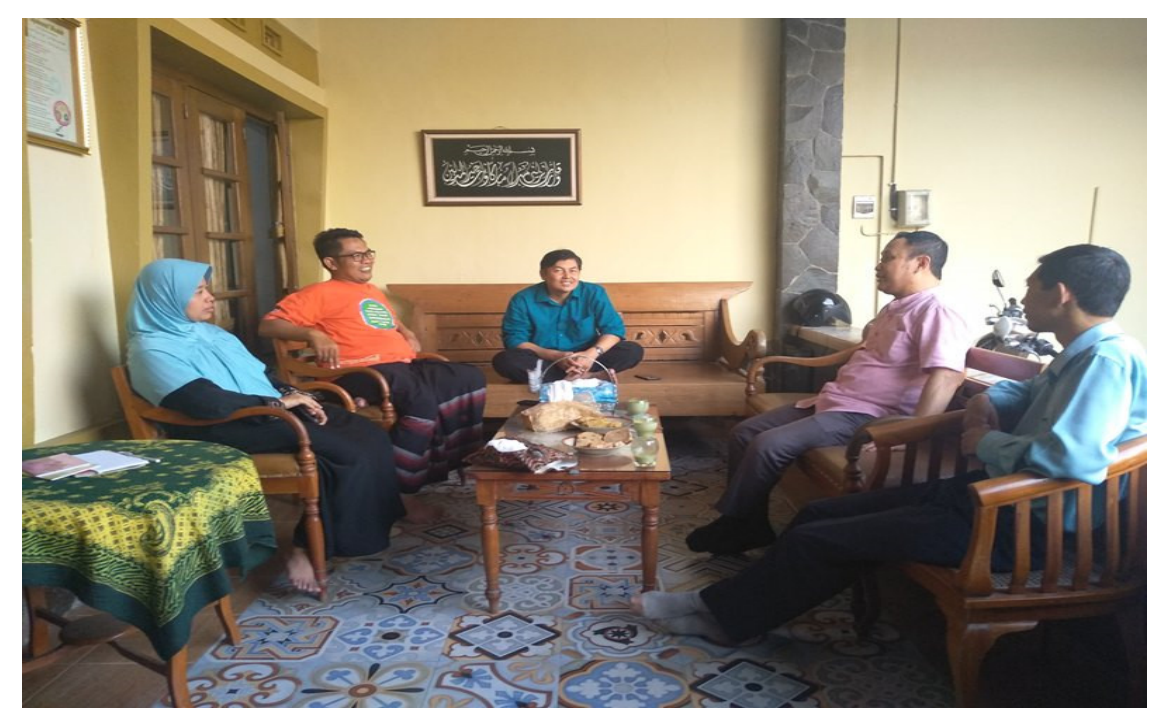

Pihak pimpinan sangat memperhatikan perlunya kewirausahaan sebagaimana maksud pengabdian untuk didiseminasikan dan dibelajarkan kepada santri di Al-Muayyad. Namun demikian, sebagai sebentuk kesadaran pimpinan tentu saja hal maksud baik ini harus ditindak lanjuti menjadi kesadaran internal kelembagaan. 
Sosialisasi kedua, adalah sosialisasi kepada segenap santri Pesantren Al-Muayyad. Keberadaan santri Pesantren Al-Muayyad merupakan subjek kegiatan pengabdian masyarakat dari mitra pesantren kami. Merekalah yang akan menerima pembelajaran dan pelatihan yang akan dilaksanakan. Dan mereka pula yang diharapkan menerima manfaat dari pengetahuan maupun soft skill yang dihasilkan dari kegiatan yang akan dilaksanakan ini.

FGD Modul Kewirausahaan Islam

Focused Group Discussion (FGD) merupakan forum-forum kecil/terbatas yang berfungsi untuk membahas berbagai kegiatan, materi maupun strategi kegiatan pengabdian kepada masyarakat yang kami laksanakan. Oleh karena itu, FGD menjadi forum konsultasi dan pengayaan baik material, immaterial dan strategi yang mendukung pelaksanaan kegiatan pengabdian masyarakat.

Karena wirausaha berorientasi pada tindakan. Tindakan pemasaran dan promosi. Bisnis adalah mendayagunakan semua instrumen dan situasi kondisi untuk memasarkan produk atau jasa bisnis ke konsumen, secara virtual maupun aktual.Secara aktual akan menaikkan tingkat keuntungan bersih usaha dan dengan sendirinya menambah nilai aktiva (asset/ harta kekayaan) pelaku bisnis. Inilah substansi kewirausahaan. Substansi bisnis itu sendiri. Wajar, kalau pebisnis sukses memiliki daftar asset bersih dalam neraca usahanya. Namun yang harus dikembangkan secara berkelanjutan adalah motivasi dan inovasi.

Hasil FGD menjadi dasar penting untuk motivasi para santri diberikan motivasi (self-motivation) terlebih dahulu sebelum diberikan pelatihan kewirausahaan berbasis digital. Artinya, perlu dibukakan kesadaran yang bersifat internal dari dalam diri masing-masing peserta training, dalam hal ini adalah santri dan santri pengurus mengenai potensi dan kemampuan diri berdasarkan anjuran-anjuran normative dan nilainilai keagamaan berikut fungsi-fungsi praktis-pragmatisnya dalam kehidupan ke depan. Ini dimaksudkan sebagai pembuka cakrawala pengetahuan mengenai keadaan masa depan yang tengah berubah. Tentang revolusi 4.0 yang tengah terjadi berikut implikasi sosial ekonomi 
harus mereka pahami dari perspektif self-motivation psychology maupun perspektif normatif kegamaan yang mereka pelajari. Tidak lain, agar keseharian ilmu pengetahuan yang mereka pelajari di pesantren dapat bersinergi dan kontekstual dengan kebutuhan yang akan mereka hadapi di masa depan.

Gambar 2

Pelaksanaan FGD

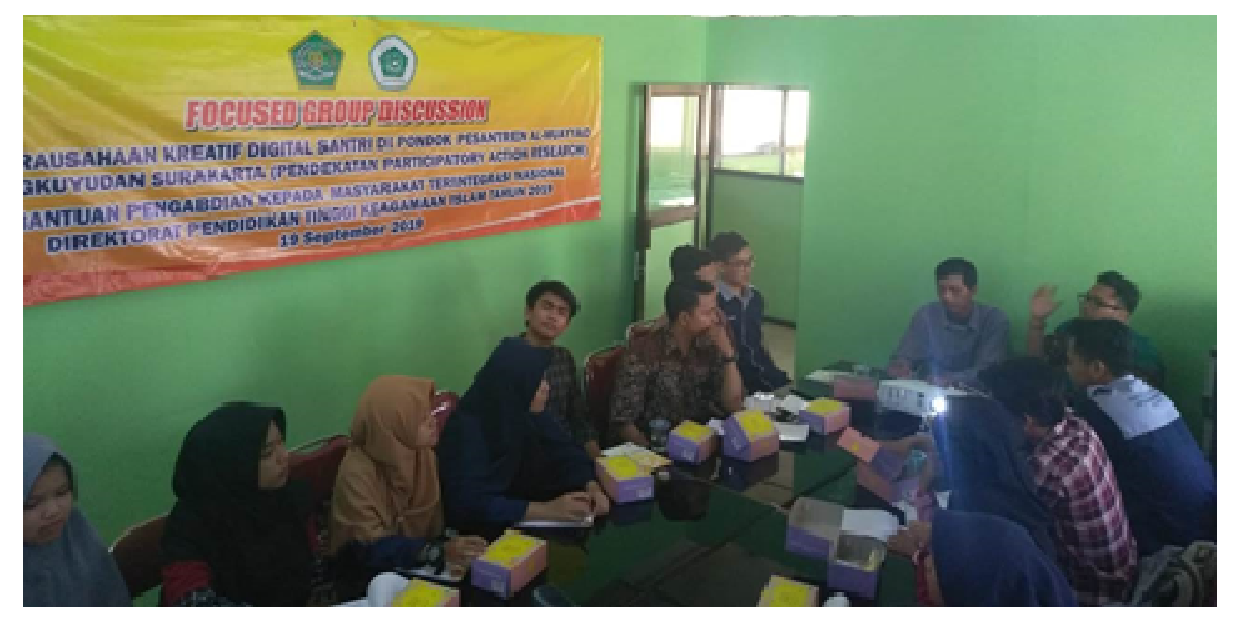

Realitas empiris kondisi dampingan di lapangan meniscayakan diberikannya upaya-upaya penumbuhan budaya kewirausahaan. Selain sebagai bekal keterampilan selepas mereka selesai belajar di pesantren, budaya wirausaha ini harus ditanamkan kepada para santri pesantren sebagai bagian dari pandangan dunia al-Qur'an atau Islam secara keseluruhan. Terlepas dari tujuan santri menuntut ilmu di pesantren yang tanpa dicampuri oleh niat-niat duniawi, tetapi sebuah pandangan dunia (world view) yang positif terhadap wirausaha dari ajaran Islam mesti diberikan dengan proporsional.

Pelatihan Kewirausahaan Dijital di Pesantren

Berdasarkan hal ini, forum merekomendasikan kepada ahli motivasi/motivator trainer untuk membedah sebuah konsep kewirausahaan dari sudut pandang nilai-nilai keislaman atau al-Qur'an yang relevan dengan usia dan kebutuhan kontemporer. Agar lebih praktis, maka dimungkinkan untuk disusun sebuah modul mini motivasi kewirausahaan (self-preneur-motivation) khusus untuk santri. Modul dimaksud dapat berisi ayat-ayat tematik tentang kewirausahaan disertai 
uraian atau pengambaran yang menarik dari sisi sejarah sahabat atau tokoh Muslim.

Hal penting lainnya adalah metode atau cara penyampaian serta para santri peserta pelatihan itu sendiri. Cara atau metode yang dipergunakan hendaknya adalah cara yang menarik dan melibatkan peserta secara aktif dan dapat mengenali potensi diri serta mengekploitasinya secara positif dalam suatu kegiatan yang terarah, dalam hal ini kewirausahaan digital.

Sedangkan peserta santri diharapkan adalah mereka yang memang memiliki interest, minat atau ketertarikan kepada bidang yang satu ini, entrepreneurship. Maksudnya, perlu dilakukan seleksi terlebih dahulu tentang siapa-siapa santri nantinya yang akan mengikuti pelatihan dan kegiatan lanjutan lainnya. Ini penting agar kegiatan dapat berjalan lebih efektif dan terarah.

Pelatihan soft skill kewirausahaan kreatif digital ini akan diberikan dengan menggunakan pendampingan kepada tiap peserta hingga masingmasing peserta dapat menerapkan soft-skillnya secara memadai. Oleh trainer, nantinya akan diberikan materi praktis bagaimana menyusun strategi membaca peluang hingga praktek pembuatan akun hingga strategi menyusun konten-konten yang bermanfaat untuk kepentingan memulai sebuah kewirausahaan.

Satu rekomendasi yang penting lagi adalah perlunya kegiatan selain motivasi dan pelatihan yang berada di luar ruangan. Maksud kegiatan ini adalah sebagai contoh praktis mengenai kewirausahaan yang berbasis digital yang dapat dijadikan model atau contoh baik dalam bentuk fisik enterpreneushipnya maupun sebagai contoh untuk pengembangan budaya kewirausahaan digitalnya.

Bentuk ideal kegiatan ini sesungguhnya adalah pemagangan santri peserta pelatihan di pusat-pusat kewirausahaan yang sudah berjalan. Melalui pemagangan, mereka akan mendapat pengalaman nyata bagaimana sebuah usaha itu dijalankan. Bagaimana menerapkan Soft-skill yang didapatkan dalam pelatihan. Lebih penting dari pengalaman teknis 
itu sesungguhnya adalah upaya untuk mengamati, merasakan dan menemukan budaya wirausaha yang mandri dalam pikiran mereka.

Alternatif kegiatan selain pemagangan adalah anjangsana wirausaha kepada beberapa pihak atau tokoh pengusaha yang dianggap sukses dalam bidang kewirausahaan yang relevan. Maksud anjangsana sesungguhnya tak berbeda dengan pemagangan di atas. Hanya saja waktu pelaksanaan dapat dipersingkat. Demikian pula cara pelaksanaannya dapat dilakukan dengan metode Study tour, sehingga menyenangkan dan menghibur, tetapi pada saat yang sama memberikan pengalaman dan pengetahuan sekaligus. Namun demikian, kedalaman pengalaman menjadi berbeda dan berkurang dibandingkan pemagangan.

Dari ketiga tersebut dipilih strategi anjangsana yang dianggap lebih sesuai dengan pelaksanaan. Pertimbangan bahwa santri masih terikat kuat dengan jadwal belajar dalam pesantren diutmakan. Anjangsana tidak mengganggu jadwal secara berkelanjutan namun masih bisa memberikan sentuhan-sentuhan motivatif dan inspiratif bagi pembentukan kemandirian santri dalam pelatihan kewirausahaan ini.

\section{Penutup}

Pendidikan Kewirausahaan di pesantren perkotaan menjadi lebih relevan bila telah disesuaikan dengan kondisi social yang berkembang di lingkungan pesantren. al-Muayyad telah menyadari dampak dari berkembangnya teknologi komunikasi dalam media social. Pengaruhnya bisa baik dalam segi positif maupun negatif. Terlebih lagi setiap industri memerlukan metode untuk memasarkan produk atau jasanya dengan sedemikian rupa, mulai dari cara yang tradisional maupun modern yang berbasis internet. Hal ini ditunjukkan dengan meningkatnya kebutuhan masyarakat akan informasi. Informasi yang sesuai dengan latarbelakang budaya masyarakat akan diterima, sedangkan yang tidak sesuai akan cenderung diabaikan atau bahkan ditolak. Karena itu, santri pengguna media social dituntut agar dapat memahami dimana mereka akan menyebarkan informasi atau mengetahui khayalak sasarannya sekaligus latar agama dan budaya yang dimiliki. 
Dengan telah masuknya pengaruh kewirausahaan dalam pesantren seperti di al-Muayyad, maka santri bisa terlibat langsung melalui pemanfaatan media dijital sosial dalam memasarkan dan memperkenalkan produk serta potensi lokal yang ada di sekitar pesantren ataupun tempat asalnya. harapan kemudian pesantren bisa memajukan negara Indonesia menuju ASEAN Community 2015 oleh rakyat dan untuk rakyat. Pemerintah melalui Kemenkominfo bisa menjadi katalis dalam pemberdayaan pesantren guna penguatan kesejahteraan umat melalui pengembangan kemitraan pesantren dalam kewirausahaan dijital. Focus demikian yang mengarah pada media sosial yang sedang digalakkan oleh lembaga departemen RI tersebut.

\section{Daftar Pustaka}

Ansori, Ansori. "Model Pengembangan Kewirausahaan Santri Melalui Pondok Pesantren Berbasis Budaya Agribisnis Tanaman Palawija.” Didaktik 8, no. 1 (2014).

Bandoko, Bandoko, A Turmudzi, dan M.N.K Al Amin. "Pemberdayaan Usaha Maz Zakki Tahun Pada Badan Amil Zakat Nasional Kota Yogyakarta." Nuansa Akademik: Jurnal Pembangunan Masyarakat 5, no. 1 (Juni 16, 2020): 53-62.

Baum, Fran, Colin MacDougall, dan Danielle Smith. "Participatory action research." Journal of Epidemiology and Community Health 60, no. 10 (Oktober 2006): 854-857.

Chotimah, Chusnul. "Pendidikan Kewirausahaan Di Pondok Pesantren Sidogiri Pasuruan.” Inferensi 8, no. 1 (September 2014): 114-136.

Dhofier, Zamakhsyari. Tradisi Pesantren Memadu Modernitas untuk Kemajuan Bangsa. Yogyakarta: Nawesea Press, 2009.

Djohani, Rianingsih, ed. Berbuat Bersama Berperan Setara: Acuan Penerapan Participatory Rural Appraisal. Bandung: Studio Driya Media, 1996.

Fauroni, Lukman, Munawar Ahmad, dan Awan Kostradiharto. PTKI Entrepreneur Gagasan dan Praktik. Diedit oleh Erham Budi Wiranto. Yogyakarta: Kurnia Kalam Semesta, 2016.

Fauroni, R Lukman. Model Bisnis ala Pesantren, Filsafat Ukhuwah Menembus Hypermarket Memberdayakan Ekonomi Umat. Yogyakarta: Kaukaba-Bisyar consulting, 2014.

H., Ahmad Nadjib, Muh. Jamaluddin, Hilman Haroen, Taufik Nugroho, dan Paiman Paiman. "Penanaman Nilai-Nilai Kemasyarakatan Di Pesantren Modern." Nuansa Akademik: Jurnal Pembangunan Masyarakat 4, no. 1 (Juni 25, 2019): 17-32.

Hayati, Keumala, dan Indra Caniago. "Kewirausahaan Teknologi Digital: Potensi Pemberdayaan Pebisnis Milenial.” In Prosiding Seminar Nasional Fisip Unila (SEFILA)-3 Tahun 2019 Agenda Baru Pembangunan Indonesia Berbasis Local Knowledge, 135-138. 
Metro: Universitas Lampung, 2019.

Heraningsih, Sarah Fiebrina, R. Rainiyati, dan Ahmad Riduan. "Enhanching Santri's Capabilities through the Skills to Convert Used Goods into Artistic Products in the Sungai Duren Village.” In Proceeding of Community Development, 2:379, 2019.

Imroatun, Imroatun. "Kontribusi Lembaga Pendidikan Agama Islam Dalam Penguatan Identitas Bangsa." Jurnal Ilmiah Bidang pendidikan Studia Didaktika 8, no. 1 (2016).

Israfil, Israfil. "Pesantren dan Kewirausahaan (Studi terhadap Pesantren Darul Khair Masing Kabupaten Banggai).” Equilibrium: Jurnal Pendidikan 5, no. 2 (Januari 2017): 160-168.

Juliawati, Nia. "Membangun Kewirausahaan: antara Digital Ekonomy dan Human Economy" (2018): 1-24.

Meria, Aziza. "Penyelamatan Akidah Huffadz Daerah Terluar melalui Bimbingan Agama dan Mental di Sumatera Barat." In ICON UCE 2016, 829-856. Surabaya: UIN Sunan Ampel, 2016.

Musaropah, Umi, Suharto Suharto, Daluti Delimanugari, Agus Suprianto, Rubini Rubini, Retno Kurnianingsih, dan Citra Ayudiati. "Pengembangan Kewirausahaan Berbasis Industri Kreatif Bagi Jamaah Wanita Majelis Taklim Di Desa Kepek.” Nuansa Akademik: Jurnal Pembangunan Masyarakat 4, no. 2 (Desember 28, 2019): 79-90.

Mustofa, Ali. "Manajemen Kewirausahaan Pondok Pesantren Berbasis Agrobisnis (Studi Kasus di PP Mukmin Mandiri dan PP Nurul Karomah).” Jurnal Kependidikan Islam 6, no. 2 (2015): 25-48.

Nadjih, Difla, dan F Setiawan Santoso. "Sosialisasi Fikih Lingkungan Usulan Pemberdayaan Majelis Taklim Di Desa Nelayan." Ulumuddin : Jurnal Ilmu-ilmu Keislaman 5, no. 2 (2015): 65-73.

Nugroho, Taufik. "Reorientasi Peranan Pesantren Pada Era Pembangunan Menuju Partisipasi Pemberdayaan Masyarakat Bawah." Ulumuddin: Jurnal Ilmu-ilmu Keislaman 7, no. 2 (2017): 147-155.

Prastomo, Wiranthi, Muhiyatul Huliyah, Moh. Nasrudin, Intan Kusumawati, Nuryati Nuryati, dan A.N. Ari Bowo. "Hizbul Wathan Bagi Pendidikan Kemandirian Tingkat Sekolah Dasar." Nuansa Akademik: Jurnal Pembangunan Masyarakat 4, no. 1 (Juni 25, 2019): 47-62.

Santoso, Fattah Setiawan. "Lingkungan Keluarga Sebagai Awal Pengembangan Kewirausahaan Islam.” Nuansa Akademik: Jurnal Pembangunan Masyarakat 5, no. 1 (Juni 16, 2020): 13-22.

Soetomo. Strategi Pembangunan Masyarakat. Yogyakarta: Pustaka Pelajar, 2010.

Widodo, Widodo, Diah Rina Kamardiani, dan Lis Noer Aini. "Kewirausahaan Jamur Tiram Di Pondok Pesantren." BERDIKARI : Jurnal Inovasi dan Penerapan Ipteks 4, no. 1 (Februari 2016): 2330 . 